\title{
EMPIRICAL OBSERVATION IN THE SEARCH OF STRATEGY FOR DEVELOPMENT OF E-LEARNING: CASE OF NATIONAL UNIVERSITIES IN UZBEKISTAN
}

\author{
Konstantin Ivanovich Kurpayanidi* \\ *Ph D in economics, \\ professor of the Russian academy of \\ natural sciences, \\ Fergana polytechnic institute, \\ Fergana, \\ Uzbekistan
}

\author{
Alisher Makhmudovich \\ Abdullaev ${ }^{* *}$ \\ ** $\mathrm{PhD}$ in Economics, \\ Associate Professor of Economics, \\ Fergana Polytechnic Institute, \\ Fergana, Uzbekistan
}

Article DOI: https://doi.org/10.36713/epra4235

\begin{abstract}
Majority of universities in the world are implementing technology enhanced learning in order to improve education and help students to develop learning. Nowadays technology enhanced learning offers universities with all context of education and universities are trying to apply it. One such case is the TARCI (Tashkent Automobile and Road construction institute) in Uzbekistan that is subject of this project. The university's current system is not reliable; also it is outdated in terms of its structure; and need to be replaced with e-learning system. In thisresearch study using a questionnaire as data collection techniques. This data collection was necessary as none of the interviewed individuals had experience with any e-learning systems. The analysis of the data shows positive attitude students for implementing an elearning system. This proposed system is based on NodeJS and Elgg software and it is believed to be a full scale elearning system that offers courses for students in TARCI. Through user requirements, the project comes up with a reliable e-learning system that will help the TARCI's administration manage courses and monitor students' progress. Hence therefore the collaboration between students and staff would be improved with developed e-learning system.
\end{abstract}

KEYWORDS:e-learning, educational content, website, learning process, online access, teaching.

\section{INTRODUCTION}

Nowadays, using e-learning system in education is becoming, without doubt, more and more important learning method. E-learning system is being used in universities and in higher education, and also in organizations that look for accurate and continuous formation of their employees. One simple activity of this type of learning is the process of learning evaluation; it means to value the earned knowledge by the students. The evaluation is the movement for the student to verify the reached knowledge in the learning process. In a summary, the evaluation process allows the student to compare the acquired knowledge with the expected one in the formative action and thus to determine if the objectives have been achieved correctly.

The advent of e-learning is mainly due to the widespread use of ICT in education. Today, elearning has its own standards that are developed by Instructional Management System (IMS). E-learning has a Learning Management System (LMS), which consists of the tools for the creation, storage, use, educational content delivery and management in the multiplayer mode. The main thing that makes eLearning unique is an opportunity of repeatedly usage of once created multimedia educational content, including online access in the real time. User not only observes the creative process of content creation, but also can participate in establishing learning process. E-learning creates educational content around the social networks, forums, and chat rooms.

E-learning allows converting the content of education, improving mobility and creative curricula and programs; it provides the possibility of designing and constructing a variety of tools for building professional competence. More and more universities world over are deploying e-learning system for the sake of improving learning process efficiency and student's knowledge quality.

Great attention to the higher education in Uzbekistan is paid to the improvement of the educational system and training of qualified specialists. On the basis of the president's decree dated February 28, 1992, twenty-four new institutions 
of higher learning and their branches to train specialists for principle branches of the national economy were established.

Today there are 61 institutions of higher learning function in the republic, including 16 universities, 39 teacher training institutes, medical, technical, economic, agricultural, and other institutes. About 300 thousand students master 276 specialties there. The oldest higher Institutions in Uzbekistan are the National University named after Ulugbek, the Technical Institute (Polytecnical Institute). Since 1991 the number of higher educational institutions has increased by $30 \%$. New higher educational institutions have appeared: The University of World

Economy and Diplomacy, Academy of State and Public Structuring, Academy of Armed Forces, Academy of Ministry of Internal Affairs. There are also few branches of foreign universities, such as Branch of Lomonosov Moscow state university, Russian University of oil and gas, Singapore university of management and others.

TARCI (Tashkent Automobile and Road Construction Institute) in Central Asia is the only institution of higher education in this area. Institute situated in the center of the capital of Uzbekistan. There are 4000 students who enter the institute every year, to obtain their bachelor's and master's degrees.

The main objective of this study is to explore ways to develop e-learning for national universities in Uzbekistan. Current study also made attempt to seek solutions for problems by answering following questions:

1. What is the current situation with learning process in national universities?

2. Which e-learning model is suitable for Uzbekistan universities?

3. How e-learning can benefit learners, practitioners and educational institutions within Uzbekistan?

In this research it is anticipated to employ a relevant research methodology to analyze the data. Obtained results will lead to suggestions for the development appropriate e-learning model that can benefit students and universities, which would in turn enhance learning process.

The study will concentrate on the e-learning in Uzbekistan universities analyzing e-learning system for Uzbekistan universities. It includes using "nodeJS" and "elgg" as Learning Management System (LMS) to analyze effective online learning web site for national universities.

Basically, there are two main objectives:

1. Investigate the role of elearning system in education processes;

2. Determine the current situation of learning process in Uzbekistan universities to determine and analyze suitable e-learning model for the universities.
Also, there is a practical problem, which current study will solve given that Uzbekistan is a country relatively new to e-learning practices. Thus, this research aims to provide a knowledge foundation work that brings following benefits : convenience and portability (reading, uploading, downloading materials at any time), flexibility (use most suitable tools for learning style), elimination geographical barriers to open up broader education options; 24/7 accessibility that makes scheduling easy and allows a greater number of people to attend classes.

\section{SERVQUAL}

The SERVQUAL service quality model was developed by a group of American authors, 'Parasu' Parasuraman, Valarie Zeithaml and Len Berry, in 1988. It highlights the main components of high quality service. The SERVQUAL authors originally identified ten elements of service quality, but in later work, these were collapsed into five factors reliability, assurance, tangibles, empathy and responsiveness - that create the acronym RATER.

Businesses using SERVQUAL to measure and manage service quality deploy a questionnaire that measures both the customer expectations of service quality in terms of these five dimensions, and their perceptions of the service they receive. When customer expectations are greater than their perceptions of received delivery, service quality is deemed low.

In addition to being a measurement model, SERVQUAL is also a management model. The SERVQUAL authors identified five Gaps that may cause customers to experience poor service quality.

\section{LITERATURE REVIEW \\ 2.1 E-learning}

It goes without saying that education is the best investment and a route to better life. New internet technologies made for the development of methods for delivery in education. E-learning was successfully implemented into the curriculum of many schools and colleges and as the result demonstrated how effective ICT use can be in supporting learning and teaching across a wide range of subject areas. If we look through the term "elearning" in Wikipedia it turns out that it belongs to European programs in the field of education and promotes the penetration of ICT in all learning systems and environments. E-learning is becoming leading in all fields of education and learning policy. It can be freely said that it has a great potential to change teaching and learning drastically. Notably, by developing capital infrastructure and providing quality interactive content ICT can transform institutions' delivery services. It can also be used in improving supporting teacher teaching and assessment. E-learning includes the fields of online 
learning, web-based training and technologydelivered instruction as well. It is a virtual world that stimulates students to take part in the educational process as they are involved in the activity of exploring and playing with the lessons material, communicating and cooperating with other students and teachers in performing several tasks such as description of electronic commerce issues that is the most attractive topic in the new information society. Usually traditional classes and seminars are focused on group learning whilst e-learning enables students self-paced and individual learning at home. These home based learning courses help students to arrange their time the way they want and take additional courses to learn or improve their skills if they find this necessary. E-learning differs from traditional courses as it provides wide range of exercises, animation, sound and testing that helps to keep student's attention and interact in the teaching process effectively.

Benefits of e-learning to students, faculty and stuff cannot be overestimated. Access to learning materials at any time helps the student to refresh his memory and will never lose the course syllabuses. Elearning also enables trainee to fulfill requirements for a degree as it is an ideal tool for certification and his results and progress can be tracked. Lectures can use e-learning materials as lecture notes or presentations, syllabus, tutorial, assignments, quizzes, tests or exercises to support presentations with ancillary tools. E-learning increases education productivity and profitability, more over according to Charles Clarke's paper "Foreword to Towards a Unified e-Learning Strategy" (July 2003) "E-learning has the potential to revolutionize the way we teach and how we learn. A great deal of progress has been made so far, but there is much more to do. E-learning can take us a further step forward. This is about embedding and exploiting technologies in everything we do, and getting ICT embedded across the curriculum for all subjects and in all pedagogues."

What is e-learning? E-learning involves the use of a computer or electronic device (e.g. a mobile phone) in some way to provide learning, educational or learning material (Derek Stockley 2003). We can define e-learning as 'the use of technologies in learning opportunities'. This is a very broad definition but has been used in the context of the HEFCE (Higher Education Funding Council for England) e-
Learning strategy:'The Government e-learning strategy defines e-learning as any learning that uses ICT. In embedding this strategy we want to ensure that there is confident use of the full range of pedagogic opportunities provided by ICT. For HE this will encompass flexible learning as well as distance learning, and the use of ICT as a communications and delivery tool between individuals and groups, to support students and improve the management of learning". (HEFCE elearning Strategy March 2005 p.5.).

Although electronic learning or shortly elearning is the term used to indicate any electronically assisted instructions it is mostly associated with instruction offered via computer or internet. But in many ways it is associated with ALT (advanced learning technology) that deals with both methodologies and technologies in learning by using networked and multimedia technologies.

\subsection{E-learning vs. traditional education}

"Once we free ourselves from the mental limits of viewing this technology as a weak sister to face-to-face synchronous education, the potentials to revolutionize education and learning become readily apparent" (Turrof, 1995). Although there is no finding to support an opinion that the best learning is traditional and the other models are inferior or less efficient such argument exists, but research shows that e-learning is at least as good as traditional education. E-learning doesn't mean replacement of lectures or tutors it just enhances the learning process. To suit differing educational needs and aspirations of students universities must provide quality and flexibility. But it is clear that implication of increased workload requires proactive and effective management. Alongside this, transition to e-learning will inevitably lead to fundamental changes in the structure of traditional learning. And the problems associated with the change must be fully understood and taken into account before the transition-taking place. It is found that e-learning has positive effects not only on the student's commitment to the learning process but on the creations a greater commitment on the students' part to learning. According to David Rashty (2001) the following table summarizes several opinions regarding the comparison between traditional learning and eLearning: 
Table 2.1: E-learning vs. Traditional education

\begin{tabular}{|c|c|c|}
\hline & Traditional learning & eLearning \\
\hline Classroom discussion & $\begin{array}{l}\text { The teacher usually talks } \\
\text { more than the student }\end{array}$ & $\begin{array}{l}\text { The student talks at least as } \\
\text { much as or more than the } \\
\text { teacher }\end{array}$ \\
\hline Learning Process & $\begin{array}{l}\text { The learning is conducted } \\
\text { with the whole class } \\
\text { participating; there is almost } \\
\text { no group or individual study }\end{array}$ & $\begin{array}{l}\text { Most of the learning process } \\
\text { takes place in groups or by the } \\
\text { individual student. }\end{array}$ \\
\hline Subject Matter & $\begin{array}{l}\text { The teacher conducts the } \\
\text { lesson according to the study } \\
\text { program and the existing } \\
\text { curriculum }\end{array}$ & $\begin{array}{l}\text { The student participates in } \\
\text { determining the subject matter; the } \\
\text { studying is based on various sources } \\
\text { of information, including web data } \\
\text { banks and net-experts located by the } \\
\text { student. }\end{array}$ \\
\hline $\begin{array}{l}\text { Emphases in the } \\
\text { Learning } \\
\text { Process }\end{array}$ & $\begin{array}{l}\text { The students learn "what" and not } \\
\text { "how"; the students and the teachers } \\
\text { are busy completing the required } \\
\text { subject matter quota; the students } \\
\text { are not involved in inquiry-based } \\
\text { education and in solving problems, } \\
\text { but rather in tasks set by the teacher. }\end{array}$ & $\begin{array}{l}\text { The students learn "how" and less } \\
\text { "what"; the learning includes } \\
\text { research study which combines } \\
\text { searching for and collecting } \\
\text { information from web data banks } \\
\text { and authorities on the } \\
\text { communications network; the } \\
\text { learning is better connected to the } \\
\text { real world, the subject matter is } \\
\text { richer and includes material in } \\
\text { different formats. }\end{array}$ \\
\hline Motivation & $\begin{array}{l}\text { The students' motivation is low, and } \\
\text { the subject matter is "distant" from } \\
\text { them. }\end{array}$ & $\begin{array}{l}\text { The students' motivation is high due } \\
\text { to the involvement in matters that } \\
\text { are closer to them and to the use of } \\
\text { technology. }\end{array}$ \\
\hline Teacher's Role & The teacher is the authority & $\begin{array}{l}\text { The teacher directs the student to } \\
\text { the information. }\end{array}$ \\
\hline Location of Learning & $\begin{array}{l}\text { The learning takes place within the } \\
\text { classroom and the school }\end{array}$ & $\begin{array}{l}\text { The learning takes place with no } \\
\text { fixed location }\end{array}$ \\
\hline Lesson Structure & $\begin{array}{l}\text { The teacher dictates the structure of } \\
\text { the lesson and the division of time }\end{array}$ & $\begin{array}{l}\text { The structure of the lesson is } \\
\text { affected by the group dynamics. }\end{array}$ \\
\hline
\end{tabular}


From the table below an analysis for e-learning by using SWOTtool has been conducted referring to table 2.2.

\section{Table 2.2: E-learning SWOT analysis}

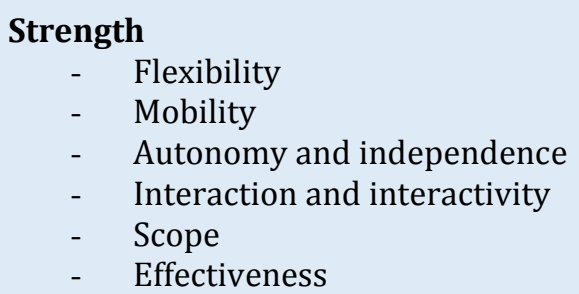

\section{Weakness}

- Insulation

- Resistance to change

- Motivation

- Not for some groups

- Learn to use ICT

- Internet connection

\section{Opportunities}

- Economics and speed

Content

$$
\text { Updating of new technologies and }
$$

- Sharing experiences

- Instructs both a large number of

subjects geographically dispersed

- Openness to new generations

- Overcrowding technology

\section{Threats}

- Internet is not accessible

- Discredit

- Evaluation System unreliable

- Prejudices this type of education

- Lack of personal contact

- High initial investment for the implementation of the system to - $\quad$ Business Training

\subsection{Benefits of e-learning}

"Good teaching is good teaching, no matter how it's done." The old adage still rings true, and eLearning brings with it new dimensions in education. E-learning believes to be highly beneficial as promotes new entrants into the higher education market. E-learning solves many problems of traditional approach. The benefits of e-learning are stated in several e-leaning web sites.

\section{Table 2.3 Summary of benefits of e-learning}

\begin{tabular}{|c|c|c|}
\hline Benefits for staff & Benefits for students & Benefits for organization \\
\hline $\begin{array}{l}\text { More effectively and efficiently } \\
\text { managed and organized course } \\
\text { materials; }\end{array}$ & $\begin{array}{l}\text { Encourage anytime-anyplace access } \\
\text { to course materials; }\end{array}$ & $\begin{array}{l}\text { E-learning can be "on demand". It } \\
\text { overcomes timing, attendance and } \\
\text { travel difficulties; }\end{array}$ \\
\hline $\begin{array}{l}\text { Reduce the need for certain } \\
\text { administrative tasks (for example, } \\
\text { making paper copies, marking tests, } \\
\text { giving out course reminders); }\end{array}$ & $\begin{array}{l}\text { Provide self-directed and self-paced } \\
\text { learning, allowing students to keep } \\
\text { track of their own progress; }\end{array}$ & $\begin{array}{l}\text { More effective training. Studies } \\
\text { indicate that trainees' retention } \\
\text { rates are as much as } 75 \% \text { higher } \\
\text { when using e-learning programs vs. } \\
\text { traditional training methods; }\end{array}$ \\
\hline $\begin{array}{l}\text { Ability to monitor student } \\
\text { participation and progress, } \\
\text { possibility of directed support and } \\
\text { quickly advices, and options for } \\
\text { making more effective use of staff- } \\
\text { student contact time; }\end{array}$ & $\begin{array}{l}\text { Increase opportunities for student } \\
\text { participation, encouraging less } \\
\text { confident students to take part; }\end{array}$ & $\begin{array}{l}\text { Less expensive training. } \\
\text { Costs go down as the number of } \\
\text { trainees' increases. This enables an } \\
\text { organization to cost-effectively } \\
\text { increase the number of personnel } \\
\text { trained, leading to higher levels of } \\
\text { employee satisfaction and superior } \\
\text { company performance; }\end{array}$ \\
\hline $\begin{array}{l}\text { Widen communication opportunities } \\
\text { with students; }\end{array}$ & $\begin{array}{l}\text { Support different learning styles } \\
\text { (using flexible learning materials); }\end{array}$ & $\begin{array}{l}\text { By using e-learning the course } \\
\text { catalogue can be expanded; }\end{array}$ \\
\hline $\begin{array}{l}\text { Help to change teachers' role from } \\
\text { "knowledge provider" to "learning } \\
\text { facilitators", promoting self-directed } \\
\text { learning; }\end{array}$ & $\begin{array}{l}\text { Promote student engagement (using } \\
\text { interactive learning materials), } \\
\text { improving learner motivation and } \\
\text { satisfaction; }\end{array}$ & $\begin{array}{l}\text { Implemented correctly, it can reduce } \\
\text { some of the cost associated with } \\
\text { education; }\end{array}$ \\
\hline $\begin{array}{l}\text { Reduce large-group teaching and } \\
\text { increase time spend with small } \\
\text { groups or individuals; }\end{array}$ & $\begin{array}{l}\text { Enhance opportunities } \\
\text { collaborative group work; }\end{array}$ & \\
\hline $\begin{array}{l}\text { Support the development with } \\
\text { flexible learning materials; }\end{array}$ & $\begin{array}{l}\text { Improve communication with course } \\
\text { tutor and teaching assistants; }\end{array}$ & \\
\hline
\end{tabular}




\section{RESEARCH METHODOLOGY}

Research methodology is a scientific way to get the data with the purpose and usefulness. Type of the research methods used is quantitative research. This quantitative research method sees reality / phenomenon / phenomena that are causal. This method is used to examine the population or a particular sample, the sampling technique is generally done at random, data retrieval using research instruments, quantitative data analysis or statistic in order to test the hypothesis that has been established. Types of quantitative research methods used is descriptive method. The purpose of descriptive research is to describe systematically the facts and the properties of a given population in a factual and accurate.

Stages of the study consisted of five (5) steps, as follows:

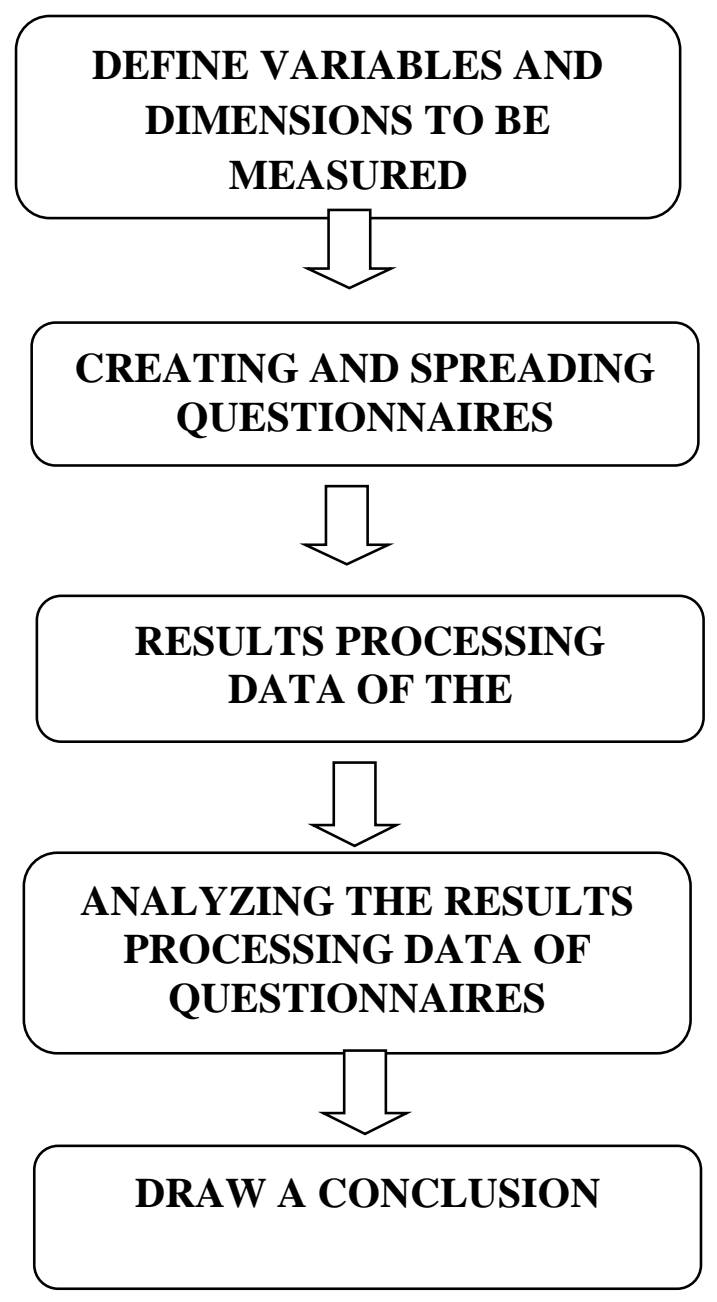

Table 3.1 Research Stages

\subsection{Define Variables and Dimensions to be Measured}

The variable is a concept that has a variation in value. The variables to be measured to determine the quality of the e-learning by using ServQual is:

- Independent Variable $(\mathrm{X})=$ website content $(\mathrm{X} 1)$, reliability $(\mathrm{X} 2)$, responsiveness $(\mathrm{X} 3)$, empathy (X4), e-learning quality (Y);

\subsubsection{Creating and Spreading Questionnaire}

In quantitative research, there are three methods of data collection, interviews, questionnaires and observation. In this research, using a questionnaire. Questionnaire

method is a technique of data collection conducted by providing the questions or written statement to the respondent. While the measurement technique used is the Likert Scale. This scale is used to measure 
attitudes, opinions, and perceptions of a person or a group of social phenomenon. The 5 point of Likert Scale is the most common scale.

Making the questioner shall refer to the variables and dimensions have beendetermined. Furthermore, the questionnaires distributed directly to the respondents selected with due regard to the characteristics and methods of sampling in accordance with conditions on the ground.

For every choice answers of respondents were scored as shown in Table 3.2 below:

Table 3.2 Answer Scale

\begin{tabular}{|l|l|}
\hline Answer scale & Score \\
\hline Strongly disagree & 1 \\
\hline Disagree & 2 \\
\hline Neutral & 3 \\
\hline Agree & 4 \\
\hline Strongly agree & 5 \\
\hline
\end{tabular}

\subsubsection{Results Processing Data of the Questionnaire}

Data were analyzed direct result of spreading questioner, then do the analysis process by using software R Programming. Further processing results can be processed using statistical models with descriptive analysis.

\subsubsection{Descriptive Data Analysis}

Descriptive data analysis is used to measure the Mean average of respondents' answers. Description of data to be presented include the value of Mean (M), Median (Me), Modus (Mo) Standard Deviation, the ideal Mean value and the ideal Standard Deviation value. To calculate the ideal Mean value and the ideal Standard Deviation value use the following formula:

$$
\text { The ideal Mean value }(\mathrm{Mi})=\frac{\text { The ideal Maximum score }+ \text { The ideal Minimum Score }}{2}
$$

$$
\text { The ideal Standard Deviation value }=\frac{\text { The ideal Maximum score }+ \text { The ideal Minimum Score }}{6}
$$

Besides that, it also presented a frequency distribution table. To determine the tendency of respondents to the research variables grouped by three rankings (Suharsimi Arikunto, 2006), namely:

1. Grouped of High Level

All respondents who had scores as much as the average score plus 1 standard deviation upward ( $>$ $\mathrm{Mi}+1 \mathrm{SDi}$ )

2. Group of Medium Level

All respondents who had scores between the average score minus 1 standard deviation and the average score plus 1 standard deviation (between $\mathrm{Mi}$ - 1 SDi to $\mathrm{Mi}+1 \mathrm{SDi}$ ).

3. Group of Low Level

All respondents who had lower scores than average score of minus 1 standard deviation $(<$ Mi - 1 SDi).

\subsubsection{Classical Assumption Test}

Classical assumption is test that conducted before multiple regression analysis test. The classical assumption test consists of normality test, multicolinierity test, autocorrelation test, and heteroskidastity test.

\section{Normality Test}

Normality test is useful to know whether the dependent variable, independent, or both normally distributed, get near too normal or not [Husein2008]. Samples were tested by the Shapiro-Wilk test. The Shapiro-Wilk test utilizes the null hypothesis principle to check whether a sample $\mathrm{x} 1, \ldots, \mathrm{xn}$ came from a normally distributed population. The test statistic is: 
$\mathrm{W}=\left(\sum \mathrm{i}=1 \mathrm{n} \alpha \mathrm{i}\right.$ X ( i ) ) $2 \sum \mathrm{i}=1 \mathrm{n}(\mathrm{X} \mathrm{i}-\mathrm{X} \&$ OverBar; ) 2

where:

$X \mathrm{i}=$ are the ordered random sample values

$\alpha i=$ are constants generated from the covariances, variances and means of the sample

( size $n$ ) from a normally distributed sample.

\section{Multicolinierity Test}

Multicolinierity test used to test whether the regression model have a correlation between independent variables [Ghozali2011]. A good regression model should be free of multicolinierity. It performed by looking at the value of Variance Inflation Factor (VIF) from each independent variable. In regression is said there have a multicolinierity if value of VIF $>10$. To determine the value of VIF is used the following formula:

$\mathrm{VIF}=1$ 1- R k 2

where $\mathrm{R} \mathrm{k} 2$ is the multiple coefficient of correlation.

\begin{abstract}
Autocorrelation Test
Autocorrelation test is used to test whether in the linear regression there is a correlation between the confounding error in $t$ period with confounding error in t-1 period. If there is an correlation means that it have autocorrelation. One of the assumptions that must be met of equation regression models are free of autocorrelation. To determine whether there is a correlation in this research is used a DurbinWatson test (dWTest) with following formula:

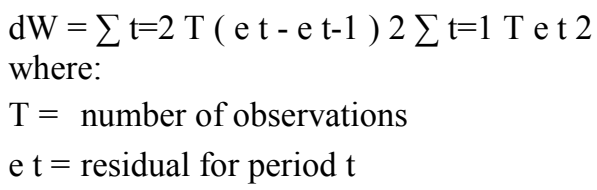

To decide whether there is autocorrelation or not, follow the provisions of the following:

$$
\begin{array}{ll}
\mathrm{dW}<\mathrm{dL}= & \text { It has positive autocorrelation }(+) \\
\mathrm{dL}<\mathrm{dW}<\mathrm{dU}= & \text { Inconclusive } \\
\mathrm{dU}<\mathrm{dW}<4-\mathrm{dU}= & \text { There is no autocorrelation } \\
4-\mathrm{dU}<\mathrm{dW}<4-\mathrm{dL}= & \text { Inconclusive } \\
\mathrm{dW}>4-\mathrm{dL}= & \text { It has negative autocorrelation }(-)
\end{array}
$$

\section{Heteroskidastity Test}

Heteroskidastity test used to test whether the regression model occurred inequality residual variance from one observation to another. The test is performed by using Breusch-Pagan test. It can be used to determine the existence of spatial heterogeneity. The test statistic for the BreuschPagan test, which has a chi-square distribution is calculated as:

$\mathrm{BP}$ chi-square test $=\mathrm{n} \times \mathrm{R}$ resid 2 with $\mathrm{k}$ degrees of freedom

where:

$\mathrm{n}=$ the number of observations

R R 2 from a second regression of the squared resid residuals from the first regression on the $2=$ independent variables

$\mathrm{k}=$ the number of independent variables

The level of trust that taken is $95 \%$ which is understood as the level to which a $95 \%$ value of the sample will represent the value of a population where the sample came from. The significant value of $95 \%$ is 0.05 . Criteria for the heteroscedasticity in a regression model is if $\mathrm{p}$ value $<0.05$. If $\mathrm{p}$-value $>0.05$ then the research can be continued.

\subsubsection{Multiple Regression Analysis}

Regression analysis is one of statistical data analysis techniques are often used to examine the relationship between several variables and predict a variable [Kutner2004]. Regression menu on $\mathrm{R}$ programming is a tool used to measure the effect of independent variables on the dependent variables and predict the dependent variable using independent variables. If the dependent variable associated only with one independent variable, then the resulting regression equation is simple linear regression. If the dependent variable is associated with more than one independent variable, the regression equation is linear multiple linear regression. 
1. Required Analysis

General Equation:

$\mathrm{Y}=\mathrm{a}+\mathrm{b} 1 \mathrm{X} 1+\mathrm{b} 2 \mathrm{X} 2+\mathrm{b} 3 \mathrm{X} 3+\ldots .+\mathrm{bnXn}$

Where:

$\mathrm{Y}=\quad$ Dependent Variable

$\alpha=$

Constants

$\mathrm{X} 1 \ldots . \mathrm{Xn}=$

Independent Variable

$\mathrm{b} 1 \ldots . . \mathrm{bn}=$

Regression Coefficients

There are three basic of assumptions should not be violated by multiple linear regression, namely:

1. It not has multicolinierity.

2. It not has autocorrelation.

3. It not has heteroskidastity.

\section{Correlation Coefficient (r/R)}

Correlation coefficient is the coefficient used to determine the relationship between variables $\mathrm{X}$ and $\mathrm{Y}$, the condition is:

1. If $r=0$ or close to 0 , then the relation is very weak or no relationship at all.

2. If $r=+1$ or close to +1 , then strong and direct relationship.

3. If $r=-1$ or close to -1 , then the relationship is strong and not unidirectional.

\section{Coefficient of determination (r2/R2)}

Coefficient of determination is a coefficient used to determine how much the independent variable (X) affects the dependent variable (Y). The coefficient of determination range is from 0 to 1 .

\section{Standard Error of Estimate}

Used to determine the accuracy of estimation equations. It can be used to measure the size of the standard error of estimate (the smaller value of his guilt then the higher the accuracy)

\subsubsection{Hypotheses Test}

Hypotheses used in this research is associative hypotheses. Associative hypotheses are allegations of whether there is a significant relationship between two or more variables. Hypotheses testing is used to determine whether there is an influence between independent variables with the dependent variable. It begins with simultaneous hypothesis testing (F), partial hypotheses test $(\mathrm{T})$ and the coefficient of determination.
1. Coefficient of Determination Test

Coefficient of determination test is used to determine how much the independent variables have an influence on the dependent variable. To determine the coefficient of determination value is used the following formula:

$\mathrm{kd}=\mathrm{r} 2 \times 100 \%$

where:

$\mathrm{kd}=$ Coefficient of determination

$r=$ Coefficient of correlation

\section{F Test}

Simultaneous test (F test) was conducted to see the effect of the independent variable on the dependent variables simultaneously. To determine the value of $\mathrm{F}$ is used the following formula:

$\mathrm{F}=\mathrm{R} 2 / \mathrm{k}(1-\mathrm{R} 2) /(\mathrm{n}-\mathrm{k})$

where:

R 2 = Coeficient of determination

$\mathrm{n}=\quad$ Number of samples

$k=\quad$ Number of independent variables

3. T Test

T test (partial) was conducted to see the effect of the independent variables to the dependent variable partially. To determine the value of $\mathrm{T}$ is used the following formula:

$\mathrm{T}=\mathrm{rn}-2$ 1- $\mathrm{r} 2$

where:

$\mathrm{r}=$ Coefficient of correlation

$\mathrm{n}=$ Number of samples

\subsubsection{Analyzing the Results Processing Data of Questionnaires}

Analytical results from the processing of questionnaires is a target that would be the purpose of achieving the level of quality of existing information systems. The end result can be expressed in a numerical value that reflects the interests of the variables and dimensions in user satisfaction performance. Determination of the value of these results are based on the gap between expectations and satisfaction received today. Value negative gap means a lower than expected. 


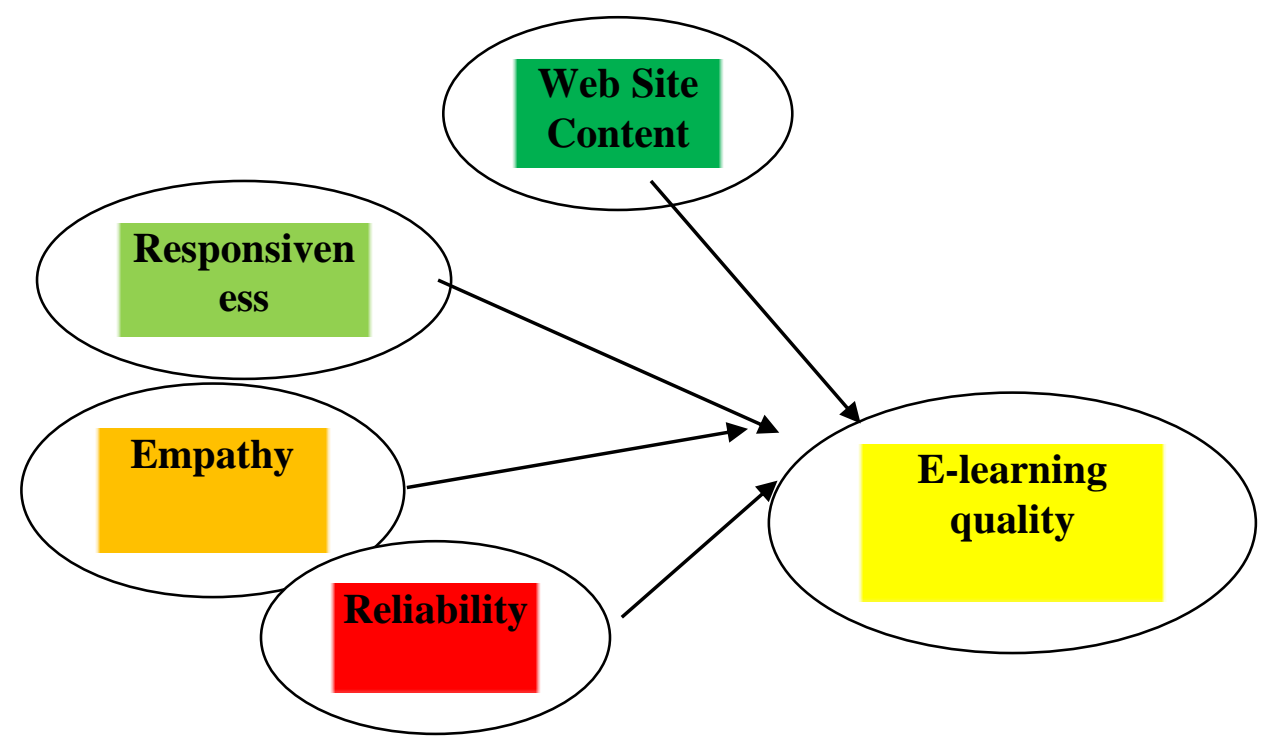

\subsection{Variable and Variable Operational Research}

In the research, should have a good measuring tool. This measure is usually referred to as the research instrument. Research instrument is a tool used to measure the natural and social phenomena being observed. Specifically, it is named as a research variable.
There is one variable used in this research, the independent variable. The independent variable is the variable that affects or is the cause of the change or the emergence of the dependent variable.

The independent variable is the data obtained from the factors contained in the End User Computing Satisfaction method to determine user satisfaction of the students in Uzbekistan.

Operational variables used in this research are presented below in Table3.4:

Table 3.3 Variable Operational Research

\begin{tabular}{|l|l|l|}
\hline & \multicolumn{1}{|c|}{ Statement } & \multicolumn{1}{|c|}{ Scale } \\
\hline \multirow{5}{*}{ Empathy } & $\begin{array}{l}\text { The instructor is genuinely concerned about the } \\
\text { students(EMP1) }\end{array}$ & $1-5$ \\
\cline { 2 - 3 } & $\begin{array}{l}\text { The instructor understands the individual needs of } \\
\text { students(EMP2) }\end{array}$ & $1-5$ \\
\cline { 2 - 3 } Responsiveness & $\begin{array}{l}\text { The instructor has the student's best long-term interests in } \\
\text { mind(EMP3) }\end{array}$ & $1-5$ \\
\cline { 2 - 3 } & $\begin{array}{l}\text { The instructor encourages and motivates students to do their } \\
\text { best(EMP4) }\end{array}$ & $1-5$ \\
\hline \multirow{5}{*}{ Reliability } & $\begin{array}{l}\text { The instructor quickly and efficiently responds to student } \\
\text { needs(RES1) }\end{array}$ & $1-5$ \\
\cline { 2 - 3 } & $\begin{array}{l}\text { The instructor is willing to go out of his or her way to help } \\
\text { students(RES2) }\end{array}$ & $1-5$ \\
\cline { 2 - 3 } & $\begin{array}{l}\text { The instructor always welcomes student questions and } \\
\text { comments(RES3) }\end{array}$ & $1-5$ \\
\hline & \begin{tabular}{l} 
The instructor consistently provides good lectures(REL1) \\
\cline { 2 - 3 }
\end{tabular} & The instructor is dependable(REL2) \\
\cline { 2 - 3 } & $\begin{array}{l}\text { The instructor reliably corrects information when } \\
\text { needed(REL3) }\end{array}$ & $1-5$ \\
\hline
\end{tabular}


EPRA International Journal of Multidisciplinary Research (IJMR) - Peer Reviewed Journal Volume: 6 | Issue: 4 | April 2020 || Journal DOI: 10.36713/epra2013 || SJIF Impact Factor: 5.614||ISI Value: 1.188

\begin{tabular}{|l|l|l|}
\hline \multirow{5}{*}{ Web site content } & The web site uses audio elements properly(WSC1) & $1-5$ \\
\cline { 2 - 3 } & The web site uses video elements properly(WSC2) & $1-5$ \\
\cline { 2 - 3 } & The web site uses animations/graphics properly(WSC3) & $1-5$ \\
\cline { 2 - 3 } & The web site uses multimedia features properly(WSC4) & $1-5$ \\
\cline { 2 - 3 } & The web site provides useful information(WSC5) & $1-5$ \\
\cline { 2 - 3 } & The web site provides accurate information(WSC6) & $1-5$ \\
\cline { 2 - 3 } E-learning quality & The website provides high quality information(WSC7) & $1-5$ \\
\cline { 2 - 3 } & The information on the web site is relevant to me(WSC8) & $1-5$ \\
\hline & $\begin{array}{l}\text { Your perception of the overall quality of the instruction you get } \\
\text { from online learning is (poor-excellent) (eLQ1) }\end{array}$ & $1-5$ \\
\cline { 2 - 3 } & The instructional web site seems to be up to date(eLQ2) & $1-5$ \\
\cline { 2 - 3 } & The instructional web site works well(eLQ3) & $1-5$ \\
\cline { 2 - 3 } & The instructional web site has clear instruction(eLQ4) & $1-5$ \\
\hline
\end{tabular}

\subsection{Variable, Definition and Attribute}

In this section will explain the variables that are used together with their explanations and the attributes.

\begin{tabular}{|c|c|c|}
\hline Variable & Definition & $\begin{array}{c}\text { Attribute } \\
\end{array}$ \\
\hline Reliability & $\begin{array}{l}\text { Refers to the ability to provide } \\
\text { the promised service accurately } \\
\text { and reliably. }\end{array}$ & $\begin{array}{l}\text { Realizes non-functional } \\
\text { requirements used to evaluate } \\
\text { the performance of a system }\end{array}$ \\
\hline Responsiveness & $\begin{array}{l}\text { The willingness to help users and } \\
\text { provide proper attention. }\end{array}$ & $\begin{array}{l}\text { Has a positive association } \\
\text { with students' perceptions of e- } \\
\text { learning quality. }\end{array}$ \\
\hline Empathy & $\begin{array}{l}\text { Includes the care and individual } \\
\text { attention to the users. }\end{array}$ & $\begin{array}{l}\text { Has a positive association } \\
\text { with students' perceptions of e- } \\
\text { learning quality. }\end{array}$ \\
\hline User Satisfaction & $\begin{array}{l}\text { The attitude of a user to the } \\
\text { computer system (s)he employs } \\
\text { in the context of his/her work } \\
\text { environments }\end{array}$ & $\begin{array}{l}\text { Has a positive association } \\
\text { with students' perceptions of e- } \\
\text { learning quality. }\end{array}$ \\
\hline Web Site Content & $\begin{array}{l}\text { Can be defined as the } \\
\text { presentation and layout of } \\
\text { information and functions that } \\
\text { capture the overall firm presence } \\
\text { and its public image, and is } \\
\text { assumed to affect how a } \\
\text { customer perceives web service } \\
\text { quality. }\end{array}$ & $\begin{array}{l}\text { Has a positive association } \\
\text { with students' perceptions of e- } \\
\text { learning quality. }\end{array}$ \\
\hline E-learning quality & $\begin{array}{l}\text { The student needs to make } \\
\text { decisions and learn from the } \\
\text { consequences }\end{array}$ & $\begin{array}{l}\text { Has a positive association } \\
\text { with students' perceptions of e- } \\
\text { learning quality. }\end{array}$ \\
\hline
\end{tabular}




\subsection{SERVQUAL and learning assessment}

The SERVQUAL service quality model was developed by a group of American authors, 'Parasu' Parasuraman, Valarie Zeithaml and Len Berry, in 1988. It highlights the main components of high quality service. The SERVQUAL authors originally identified ten elements of service quality, but in later work, these were collapsed into five factors reliability, assurance, tangibles, empathy and responsiveness - that create the acronym RATER.

Businesses using SERVQUAL to measure and manage service quality deploy a questionnaire that measures both the customer expectations of service quality in terms of these five dimensions, and their perceptions of the service they receive. When customer expectations are greater than their perceptions of received delivery, service quality is deemed low.

In addition to being a measurement model, SERVQUAL is also a management model. The SERVQUAL authors identified five Gaps that may cause customers to experience poor service quality.

Since its development over 25 years ago, SERVQUAL has attracted considerable attention and has gone through numerous refinements. It has been shown to be an effective tool for measuring customer satisfaction and behavioral intentions in many areas of interest (Carman, 1990; Cronin \& Taylor, 1992; Cuthbert, 1996; Dabholkar, 1995; Parasuraman, Zeithaml, \& Berry, 1988) and industries, including restaurants and tourism (Olorunniwo et al., 2006).

The scale consists of the following dimensions (Parasuraman et al., 1988):

1. "Usability quality" which include the physical facilities, equipment, and appearance of personnel.

2. "Information quality" which reflects the ability to perform the promised service dependably and accurately.

3. "Interaction quality" which include the willingness to help customers and provide prompt service.

Stodnick and Rogers (2008) were among the first to use SERVQUAL to evaluate how traditional students perceive learning quality. Of the five SERVQUAL dimensions, they found that three (assurance, empathy, and reliability) were significant predictors, and so concluded that the instrument could be used to assess student satisfaction and their perception of instruction quality. Our study adopts the Stodnick and Rogers' questionnaire with some modifications to reflect an e-learning environment. It can be mentioned that online education is a type of service whose quality, for example, can be assessed with modified SERVQUAL.

\subsection{SERVQAL dimensions and hypotheses}

All of our constructs (as well as the hypotheses in the following section) are based on the precepts of the principles of CTML, ISCM, and modified SERVQUAL as discussed above. Wherever possible, we use previously validated questions from earlier research. We adopt the version of SERVQUAL used by Stodnick and Rogers (2008) because it is the most comprehensive scale that has been modified to reflect a learning environment. However, we replace "Tangibles" with "website content" to more appropriately reflect the online environment. The "Website Content" dimension has been used in previous studies (Cao, Zhang, \& Seydel, 2005; Santos, 2003). While items in the "Satisfaction"construct (e.g., "My choice to enroll in online classes was a wise one") and the "Behavioral Intentions"' construct (e.g., "Would you recommend this e-learning to someone else?') may be considered "universal" or "global" across all service contexts, the "ELearning Quality" construct is specific to the type of service and service environment in which it is delivered. Our first set of hypotheses is based on the original four components of SERVQUAL as found in (Stodnick \& Rogers, 2008).

\section{REFERENCES}

1. Atoji, Y, Koiso, $T$, \& Nishida, S. (2002). Information filtering for emergency management.

2. Carman, J. M. (1990). Consumer perceptions of service quality: An assessment of theSERVQUAL dimensions. Journal of Retailing, 66(1), 33-55.

3. Charles Clarke. (2003). Foreword to Towards a Unified e-Learning Strategy.

4. Chiu, C. M., Hsu, M. H., Sun, S. Y., Lin, T. C., \& Sun, P. C. (2005). Usability, quality, value and $e-$ learning continuance decisions. Computers and Education, 45(4),399-416.

5. Cronin, J. J. J., \& Taylor, S. A. (1992). Measuring service quality: $A$ reexamination and extension. Journal of Marketing, 56(3), 55-68.

6. Cunliffe, D., Developing Usable Web Sites - A Review and Model,Internet Research, Vol.10: 295-308, 2000.

7. Cuthbert, P. (1996). Managing service quality in HE: Is SERVQUAL the answer? Part1. Managing Service Quality, 6(2), 11-16.

8. Dabholkar, P. A. (1995). A contingency framework for predicting causality between satisfaction and service quality. Advances in Consumer Research(22), 101-106.

9. David Rashty. (2001). Traditional Learning vs. eLearning.

10. Derek Stockley. (2003). E-learning definition and explanation (E-learning, online training, online learning). HEFCE e-learning Strategy. March 2005 p. 5.

11. Dotchin, J.A. and Oakland, J.S. (1994a), "Total quality management in services: Part 2 Service quality", International Journal of Quality \& Reliability Management, Vol. 11, No. 3, pp. 2742. 
12. Edvardsen, B., Tomasson, B. and Ovretveit, J. (1994), Quality of Service: Making it Really Work,McGraw-Hill, New York, NY.

13. Kline, P., An Easy Guide to Factor Analysis, Routledge, London, 1994.

14. Kurpayanidi, K. I. (2018). The typology of factors of increasing the innovative activity of enterprise entrepreneurs in the industry. ISJ Theoretical \& Applied Science, (10), 66.

15. Kurpayanidi, K. I. (2018). Questions of classification of institutional conditions, determining the structure of business management in Uzbekistan. ISJ Theoretical \& Applied Science, 9(65), 1-8.

16. Lewis, B.R. and Mitchell, V.W. (1990), "Defining and measuring the quality of customer service", Marketing Intelligence \& Planning, Vol. 8, No. 6, pp. 11-17.

17. Margianti, E.S., Ikramov, M.A., Abdullaev, A.M., Kurpayanidi, K.I., Khudaykulov, A. Sh., Misdiyono (2020) Role of goal orientation as a predictor of social capital: Practical suggestions for the development of team cohesiveness in SME's. Monograph. Gunadarma Pulisher, Indonesia.

18. Olorunniwo, F., Hsu, M. K., \& Udo, G. J. (2006). Service quality, customer satisfaction, and behavioral intentions in the service factory. Journal of Services Marketing,20 (1), 59-72.

19. Parasuraman, A., Zeithaml, V. A., \& Berry, L. L. (1988). SERVQUAL: A multiple-itemscale for measuring consumer perceptions of service quality. Journal of Retailing,64(Spring), 12-40.

20. Parasuraman, A., Zeithaml, V.A. and Berry, L.L. (1985), "A conceptual model of service quality andits implication", Journal of Marketing, Vol. 49, Fall, pp. 41-50.

21. Roca, J. C., Chiu, C. M., \& Martinez, F. J. (2006). Understanding e-learning continuance intention: An extension of the technology acceptance model. International Journal of Human-Computer Studies, 8,683-696.

22. Stodnick, M., \& Rogers, P. (2008). Using SERVQUAL to measure the quality of the classroom experience. Decision Sciences Journal of Innovative Education, 6(1),115-133.

23. Udo, G. J., \& Marquis, G. (2002). Factors affecting e-commerce web sites effectiveness. Journal of Computer Information Systems, 42(2), 10-16.

24. Volery, T. \& Lord, D. (2000). Critical success factors in online education. The International Journal of Education Management, 14 (5), 216 223.

25. Wisniewski, M. (2001), "Using SERVQUAL to assess customer satisfaction with public sector services", Managing Service Quality, Vol.11, No.6, pp. 380-388.
26. Zeithaml, Parasuraman\& Berry, "Delivering Quality Service; Balancing Customer Perceptions and Expectations," Free Press, 1990. 